\title{
Forested Landscapes Modelling Based on Tensors and Scenarios
}

\author{
Michel Godron \\ Department Laddys, Faculty of Geography, University Paris-Diderot, Paris, France
}

\section{Email address:}

migodron@wanadoo.fr

\section{To cite this article:}

Michel Godron. Forested Landscapes Modelling Based on Tensors and Scenarios. American Journal of Agriculture and Forestry. Vol. 7, No. 5, 2019, pp. 185-190. doi: 10.11648/j.ajaf.20190705.14

Received: June 27, 2019; Accepted: September 4, 2019; Published: September 19, 2019

\begin{abstract}
A forest is an object so complex that it can never be known in all its details. But it is possible to get a "simplified picture" of the forest functioning, i.e. it is possible to build a "model". For this purpose, a forest may be considered as a landscape, the elements of which are the model basis; each element of a forested landscape is then the forest parts occupied by the same tree species. The model is built with the knowledge of the forester, and not on a priori biological and economical equations. The forester builds directly spread sheets matrixes for each tree species by writing what he knows about the evolution of each of them. Each line of the spread sheet reports the evolution along time of a "parameter" such as trees height, average diameter, number of trees by hectare, total volume by hectare, management cost, economical products value, etc. In our case each element of forest landscape will give its own matrices, and a set of matrices is called "tensor" by mathematicians. Three types of tensors are proposed, in order to improve forest management by building scenarios. The main interest of this model is to help foresters to see more precisely the consequences of their management decisions.
\end{abstract}

Keywords: Model, Forest Silviculture, Tensors

\section{Introduction}

Some foresters from center of France asked for help to decide how to manage their forests by combining data on:

a) trees and their population dynamics,

b) costs and benefits,

c) environmental parameters,

d) etc.

The multiple combinations of these parameters are so complex that they can never be known in their all details. Then it was necessary to get a "simplified picture" of the forest functioning, i.e. to build a "model" of the forest. We could use models of linear programming, multiple regression, transition matrixes and contingency tables 1 , or ordonnancement models [2], or models using differential equations, neural networks, algebra of relations, and others black boxes. But the foresters of our region were accustomed to simpler methods [3-7] and wanted a model understandable by non-mathematicians who are not able to use the models proposed by [8-10].

The first step was to put the landscape ecology principles in operation [1]: one landscape is "a territory with a repetitive structure combining landscape elements at a kilometric scale and with a characterizable functioning". In the hierarchical pyramid of landscape classification [11], forest landscape elements are the forest parts occupied by the same tree species.

Another challenge, trees need dozens of years to get adult. Then foresters' decisions are based on forest history for at least half a century before present. These decisions will have important consequences for many dozens of years. The foresters wanted a model showing explicitly, for each variable and for each element of the forest landscape, their variations along time.

The solution was to build a mathematical model founded on rectangular spread sheets named matrixes where the columns represent variation along time of the variables written on each line. These variables play the role of parameters and are linked to each element of landscape functioning. An example of these parameters will be presented in paragraph 2.1.

Several matrixes may be combined to build a mathematical object named "tensor". For example, a tensor combining 3 matrixes looks like a book of which each page is a two dimensions matrix with $\mathrm{n}$ lines and $\mathrm{p}$ columns. In our case each page represents a landscape element functioning and the 
tensor treats all the landscape elements.

Three types of tensors will be built:

i. The first one describes potentialities of variation along time of several parameters.

ii. The second summarizes landscape elements history.

iii. The third type gives results of scenarios.

\section{Methods and results}

They will be described for each of the three types of tensors

\subsection{Building the Tensor of Potentialities}

Each tree species constituting an element of forest landscape must have its own potentialities matrix. As told before, each line is devoted to one of the parameters, and begins by the name of the parameter with the unit of measure. The other columns show what happens along time to the parameter. In order to produce tables easy to read, the value of the parameter is given not for every year but for every ten years.

For example, in Table 1, the number of trees per hectare of Pinus sylvestris for the 10 decennias are: Number of trees (n) 17501260665513431350308271231200 , and this line will be the second line in the matrix of Pinus sylvestris.
The foresters have chosen 19 parameters concerning one hectare of each of the landscape elements:

1. Cost of installation (100 euros)

2. Number of trees (n)

3. Dominant height of the trees (m)

4. Mean diameter of the trees $(\mathrm{cm})$

5. Volume of the trees $\left(\mathrm{m}^{3}\right)$

6. Actual value of the trees (100 euros)

7. Future value of the trees (100 euros)

8. Number of dead trees (n)

9. Mean diameter of the dead trees $(\mathrm{cm})$

10. Financial charges for 10 years (100 euros)

11. Number of felled trees (n)

12. Mean diameter of the felled trees $(\mathrm{cm})$

13. Volume obtained $\left(\mathrm{m}^{3}\right)$

14. Value of $1 \mathrm{~m}^{3}$ (euros $/ \mathrm{m}^{3}$ )

15. Value of the forest products (100 euros)

16. Cynegetical value for ten years (100 euros)

17. Total revenue (100 euros)

18. Financial result (100 euros)

The matrix of Pinus sylvestris will have 10 decennias (Table 1), Pseudotsuga 8 decennias (Table 2), and Quercus 110 decennias (Table 3).

\subsubsection{Pinus Sylvestris}

Table 1. Potentialities for Pinus sylvestris (1 ha).

\begin{tabular}{|c|c|c|c|c|c|c|c|c|c|c|}
\hline Year & 5 & 15 & 25 & 35 & 45 & 55 & 65 & 75 & 85 & 95 \\
\hline Cost of installation (100 euros) & 6 & 3 & 0 & 0 & 0 & 0 & 0 & 0 & 0 & 0 \\
\hline Number of trees (n) & 1750 & 1260 & 665 & 513 & 431 & 350 & 308 & 271 & 231 & 200 \\
\hline Mean height of the trees (m) & 0 & 4 & 8 & 12 & 16 & 18 & 21 & 23 & 24 & 25 \\
\hline Mean dbh of the trees $(\mathrm{cm})$ & 3 & 10 & 16 & 21 & 25 & 29 & 33 & 36 & 39 & 41 \\
\hline Volume of the trees $\left(\mathrm{m}^{3}\right)$ & 0 & 0 & 40 & 77 & 103 & 126 & 154 & 168 & 176 & 172 \\
\hline Actual value of the trees $(100 €)$ & 0 & 0 & 4 & 9 & 12 & 15 & 18 & 24 & 35 & 55 \\
\hline Future value of the trees $(100 €)$ & 0 & 0 & 13 & 25 & 33 & 40 & 49 & 54 & 56 & 55 \\
\hline Financial charges 10 years $(100 €)$ & 6 & 6 & 6 & 6 & 6 & 6 & 6 & 6 & 6 & 6 \\
\hline Number of felled trees (n) & 0 & 500 & 140 & 75 & 78 & 36 & 34 & 37 & 29 & 200 \\
\hline Mean dbh of felled trees $(\mathrm{cm})$ & 0 & 0 & 10 & 15 & 20 & 5 & 30 & 34 & 39 & 41 \\
\hline Volume produced $\left(\mathrm{m}^{3}\right)$ & 0 & 0 & 0 & 4 & 10 & 9 & 13 & 20 & 22 & 172 \\
\hline Value per $\mathrm{m}^{3}\left(\right.$ euros $\left./ \mathrm{m}^{3}\right)$ & 0 & 0 & 9 & 12 & 12 & 12 & 12 & 14 & 20 & 32 \\
\hline Value of the product $(100 €)$ & 0 & 0 & 0 & 0 & 1 & 1 & 2 & 3 & 4 & 55 \\
\hline Cynegetical value $(100 €)$ & 5 & 5 & 3 & 3 & 3 & 3 & 4 & 4 & 4 & 4 \\
\hline
\end{tabular}

Potentialities $=$ Evolution of the parameters for one hectare

\subsubsection{Pseudotsuga Menziesii}

Table 2. Potentialities for Pseudotsuga (1 ha).

\begin{tabular}{|c|c|c|c|c|c|c|c|c|}
\hline Year & 5 & 15 & 25 & 35 & 45 & 55 & 65 & 75 \\
\hline Cost of installation (100 euros) & 12 & 5 & 0 & 0 & 0 & 0 & 0 & 0 \\
\hline Number of trees (n) & 1630 & 676 & 336 & 273 & 227 & 200 & 182 & 168 \\
\hline Mean height of the trees (m) & 1 & 6 & 12 & 16 & 19 & 22 & 25 & 28 \\
\hline Mean dbh of the trees $(\mathrm{cm})$ & 2 & 8 & 16 & 24 & 31 & 37 & 41 & 44 \\
\hline Volume of the trees $\left(\mathrm{m}^{3}\right)$ & 0 & 0 & 20 & 60 & 93 & 134 & 157 & 170 \\
\hline Actual value of the trees $(100 €)$ & 0 & 0 & 2 & 8 & 15 & 25 & 39 & 58 \\
\hline Future value of the trees $(100 €)$ & 0 & 0 & 7 & 20 & 32 & 46 & 53 & 58 \\
\hline
\end{tabular}




\begin{tabular}{|c|c|c|c|c|c|c|c|c|}
\hline Year & 5 & 15 & 25 & 35 & 45 & 55 & 65 & 75 \\
\hline Mean dbh of dead trees $(\mathrm{cm})$ & 2 & 5 & 10 & 15 & 19 & 22 & 24 & 26 \\
\hline Financial charges 10 years $(100 €)$ & 6 & 6 & 6 & 6 & 6 & 6 & 6 & 6 \\
\hline Number of felled trees (n) & 0 & 100 & 55 & 50 & 13 & 15 & 13 & 168 \\
\hline Volume produced $\left(\mathrm{m}^{3}\right)$ & 0 & 0 & 2 & 6 & 4 & 9 & 9 & 170 \\
\hline Value per $\mathrm{m}^{3}\left(\right.$ euros $\left./ \mathrm{m}^{3}\right)$ & 0 & 0 & 9 & 13 & 16 & 19 & 25 & 34 \\
\hline Value of the product $(100 €)$ & 0 & 0 & 0 & 1 & 1 & 2 & 2 & 58 \\
\hline Cynegetical value $(100 €)$ & 1 & 2 & 2 & 1 & 1 & 1 & 1 & 1 \\
\hline Financial result $(100 €)$ & -17 & -9 & -4 & -4 & -4 & -3 & -4 & 53 \\
\hline
\end{tabular}

Potentialities $=$ Evolution of the parameters for one hectare

\subsubsection{Quercus Pedunculata}

Table 3. Potentialities for Quercus pedunculata (1 ha).

\begin{tabular}{|c|c|c|c|c|c|c|c|c|c|c|c|}
\hline Year & 5 & 15 & 25 & 35 & 45 & 55 & 65 & 75 & 85 & 95 & 105 \\
\hline Cost of installation (100 euros) & 6 & 5 & 2 & 0 & 0 & 0 & 0 & 0 & 0 & 0 & 0 \\
\hline Number of trees (n) & 3500 & 2320 & 1440 & 630 & 490 & 350 & 298 & 253 & 214 & 182 & 154 \\
\hline Mean height of the trees $(\mathrm{m})$ & 1 & 2 & 4 & 7 & 11 & 15 & 18 & 20 & 22 & 23 & 24 \\
\hline Mean dbh of the trees $(\mathrm{cm})$ & 1 & 8 & 14 & 20 & 25 & 29 & 33 & 37 & 41 & 44 & 47 \\
\hline Volume of the trees $\left(\mathrm{m}^{3}\right)$ & 0 & 0 & 58 & 82 & 118 & 126 & 149 & 170 & 184 & 184 & 182 \\
\hline Actual value of the trees $(100 €)$ & 0 & 0 & 1 & 2 & 5 & 8 & 12 & 19 & 33 & 48 & 62 \\
\hline Future value of the trees $(100 €)$ & 0 & 0 & 20 & 28 & 40 & 43 & 51 & 58 & 63 & 63 & 62 \\
\hline Financial charges 10 years $(100 €)$ & 7 & 7 & 7 & 7 & 7 & 7 & 7 & 7 & 7 & 7 & 7 \\
\hline Number of felled trees (n) & 500 & 750 & 300 & 120 & 110 & 45 & 40 & 35 & 28 & 26 & 154 \\
\hline Mean dbh of felled trees $(\mathrm{cm})$ & 1 & 3 & 8 & 13 & 18 & 23 & 28 & 32 & 35 & 38 & 45 \\
\hline Volume produced $\left(\mathrm{m}^{3}\right)$ & 0 & 0 & 0 & 4 & 10 & 9 & 13 & 16 & 16 & 18 & 182 \\
\hline Value per $\mathrm{m}^{3}\left(\mathrm{euros} / \mathrm{m}^{3}\right)$ & 0 & 0 & 1 & 2 & 4 & 6 & 8 & 11 & 18 & 26 & 34 \\
\hline Value of the product $(100 €)$ & 0 & 0 & 0 & 0 & 1 & 1 & 2 & 2 & 3 & 5 & 62 \\
\hline Cynegetical value $(100 €)$ & 5 & 5 & 5 & 3 & 3 & 3 & 2 & 2 & 2 & 3 & 3 \\
\hline
\end{tabular}

Potentialities $=$ Evolution of the parameters for one hectare

Obviously, for each forest species, the quality of the soil of the forest has an influence on the growth of the trees, and it is possible to build, for example, one matrix for good soils, one other for medium soils and a third one for poor soils.

The most important remark about these tables is that they were built by the foresters themselves, who could compare their opinions and feel how each parameter is important, more or less consciously, for their decisions. They admitted that, formerly, they have often decided without having gathered all the pertinent information.

\subsection{The Matrix of History}

Any landscape is the result of a long history that the model must know and take in account [12]. This history is represented by a matrix where each line is devoted to an element of landscape and one column to each decennia of the past. For example, 3 hectares of Pinus sylvestris were planted during the decennia around 1910, 2 hectares of Pseudotsuga were planted during the decennia around 1950, and 4 hectares of Quercus in 1930. Etc.

The history for the three elements of landscape is presented hereunder:

Table 4. The history of plantation (hectares) for the 3 species.

\begin{tabular}{|c|c|c|c|c|c|c|c|c|c|c|c|}
\hline \multicolumn{12}{|c|}{ History of the forest (the year is the center of the decennia where the element was installed) } \\
\hline & 1910 & 1920 & 1930 & 1940 & 1950 & 1960 & 1970 & 1980 & 1990 & 2000 & 2010 \\
\hline 1 Pinus sylvestris & 3 & 0 & 5 & 0 & 16 & 0 & 33 & 0 & 8 & 0 & 2 \\
\hline 2 Pseudotsuga & 0 & 0 & 0 & 1 & 2 & 0 & 4 & 0 & 1 & 0 & 0 \\
\hline 3 Quercus pedunculata & 1 & 0 & 4 & 0 & 5 & 4 & 4 & 1 & 5 & 0 & 1 \\
\hline
\end{tabular}

\subsubsection{The General View of the Forest}

When the area covered (hectares) by each element of landscape characterized by the forest species and the class of diameter has been observed, these data may be summarized in a general description for the whole forest. The limits of diameter for the classes of diameter acronyms are:

$2.5 \mathrm{~cm} \quad 12.5 \mathrm{~cm} \quad 22.5 \mathrm{~cm} \quad 32.5 \mathrm{~cm} \quad 42.5 \mathrm{~cm} \quad 52.5 \mathrm{~cm} \quad 62.5 \mathrm{~cm}$ $72.5 \mathrm{~cm}$ SEMI REGE PER PB PBM GBM GB TGB TTGB and the general description of the forest is: 
Table 5. The general view of the forest.

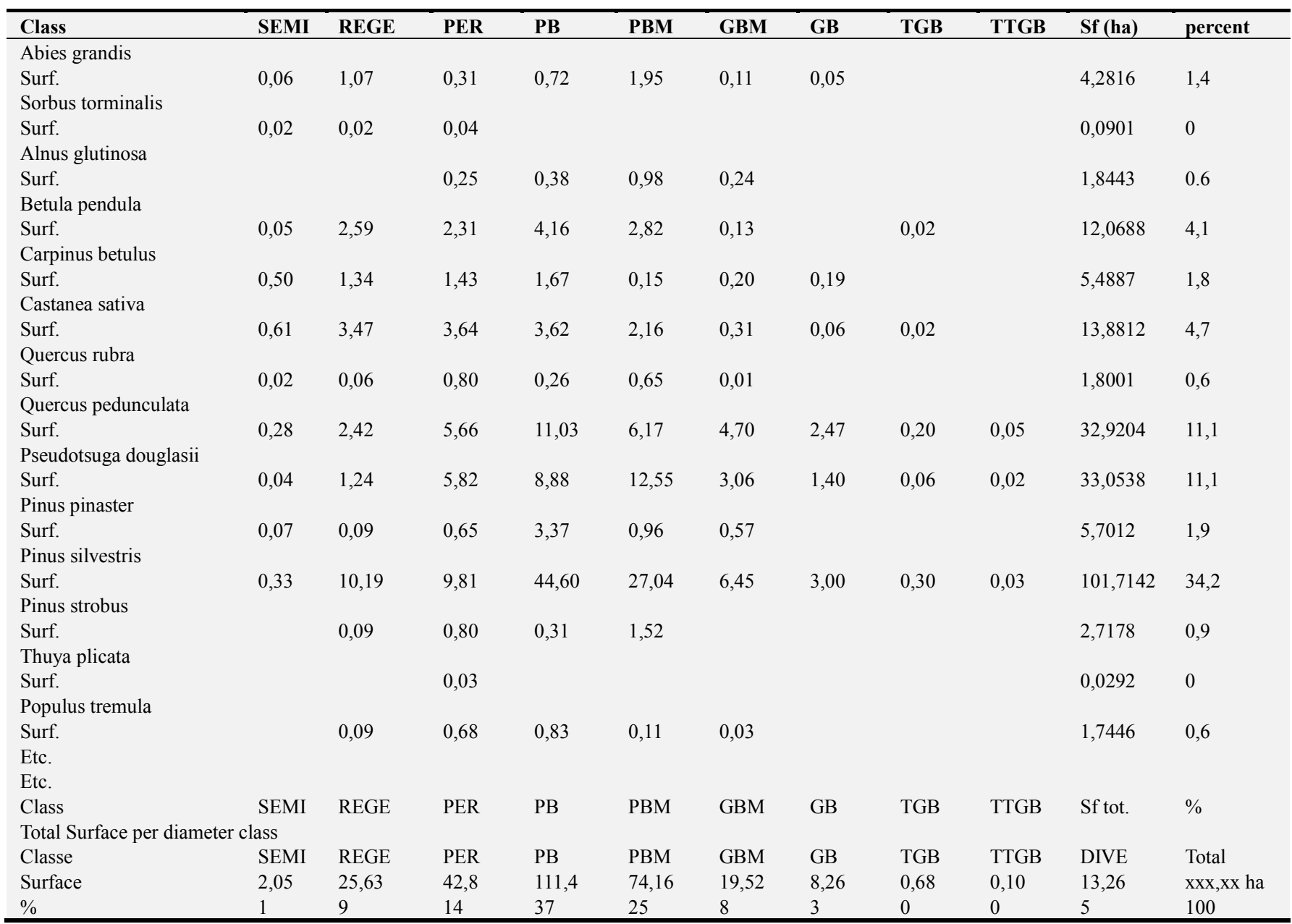

That table was very useful for the foresters who saw, in that case, that the forest observed is mainly young and that the main operations will be clearing.

It was also interesting to compute the diversity indexes of [13] and to see that the most resilient elements of landscape to climate change were those which had the greatest diversity of age of trees.

\subsubsection{The Assemblage of History and Potentialities}

The mathematical properties of tensors and matrixes permit to combine the matrix of history and the tensor of potentialities.

For example, the total volume of trees of Pseudotsuga is the sum of 4 figures for the total volume in the year 2015 :

i. the plantation of 1 ha in year 1940 gives in 2015 trees 75 years old, which the fifth line of potentialities matrix tells have a total volume of $170 \mathrm{~m}^{3}$;

ii. the plantation of 2 ha in year 1950 gives in 2015 trees 65 years old, of which total volume is 2 ha $x 167 \mathrm{~m}^{3}=314$ $\mathrm{m}^{3}$;

iii. the plantation of 4 ha in year 1970 gives in 2015 trees 45 years old, of which total volume is 4 ha $x 93 \mathrm{~m}^{3}=372$ $\mathrm{m}^{3}$;

iv. the plantation of 1 ha in year 1990 gives in 2015 trees 25 years old, of which total volume is 1 ha $x 20 \mathrm{~m}^{3}=20 \mathrm{~m}^{3}$.
And so on, for all the parameters and for all the elements of landscape: each line of the potentiality matrix multiplied by the corresponding line of history matrix gives the evolution of all the parameters in the past. The synthetic operator multiplication of tensors is easily achieved with a powerful language as Iverson's APL.

The last parameter, which is Total revenue (100 euros), is always interesting and it shows generally a contrasted evolution with some lucky periods and less favourable others. The whole result is too large to be reproduced here.

It is important to give this type of result to the forester immediately after he has built the tensor of potentialities and the tensor of history, in order to help him to see immediately how the model shows the consequences of his decisions.

Regression models, ordonnancement models, interactions between elements of landscapes, diffusion models, accessibility to the resources, cartography, etc. could be introduced after this phase of the work.

\subsection{The Scenarios}

For the example presented here, the last year present in the tensors was 2010, and it was interesting to see what may happen in the future by building scenarios. It is then necessary to pay attention at the fact that the potentialities were given for 
a limited number of years. For example, if the forester had planted 2 hectares with Pseudotsuga in the year 1920, Table 2 shows that these trees will be harvested 75 years later, in the year 1995, and nothing is known about what happened after the year 1995. So, to build the scenarios, you must tell to the model what you decide to do for these two hectares after 1995.

The simplest scenario is then to decide automatically to plant again the same species when it is harvested, in a systematical reiteration, as if the system had a perfect inertia.

For the others scenarios, the forester has liberty to try diverse types of replacement of the hectares which were harvested. For a great forest, he may also systematically do the replacements with a transition matrix.

\subsection{The Climate Change}

One of the most appreciated advantages of our model has been to help foresters to build themselves scenarios favoring species resilient to climate change, because they were unable to use the models proposed by some authors [14 15]. They could build these scenarios by modifying the growth parameters in potentialities $(\S 1.1)$ and choosing resilient species for replacements $(\S 1.3)$ and get a good final image of their forest in the shape of table 5 .

\section{Discussion}

Looking back to the typology of models [2], the tensor model is:

i. analytical,

ii. cinematic with time explicit,

iii. mathematic and digital,

iv. determinist in its first phase, probabilistic afterwards,

v. non predictive, because the aleas affecting a real territory are too numerous,

vi. fundamentally spatialized, in a heterogeneous space,

vii. auto-adaptative,

viii. built for decision making.

\subsection{The First Feed Back}

It appeared when the foresters began to build the potentialities matrixes: at first, each forester proposed its own values for each parameter, which were often very different, and a great brainstorming happened which showed clearly that each forester was not accustomed to put figures for each parameter based on his own experience. Some of the foresters were clearly too optimistic, and some others too pessimistic... As the computations include no black box, the foresters themselves could find back the causal differences between their opinions.

The potentialities are often overestimated in scientific literature, because the specialists who measure production install their experimental plots in homogeneous forests in good health, have always plenty machines and workers to do the job in good time, and more money than the common people. The potentialities estimated after the brainstorming were more realistic.

\subsection{The Sensibility of the Model}

As the tensorial computations are perfectly transparent, it is easy to see the effects of each modification of the parameters: an improvement which was appreciated by the foresters is the computation of the "sensibility" of the model about the financial result. The sensibility was computed for each parameter by measuring the change of the financial result when any figure of the parameter is improved by $10 \%$.

For example, applying the tensor model to mountains in Iran, the sensibility computation showed the interest of reducing erosion by the installation of little embankments. In the case of tropical forests in Amazonia, the most sensible parameter was the intensity of tree harvesting.

\subsection{Exact Statistics}

The model is a simplified image of the forest, and this image is never perfectly reliable. For real forests, the characterization of the elements of landscape cannot make inference to an infinite statistic universe which is certainly very different of the sample. Consequently, the comparison of two scenarios or of two forests must be done with "exact" probabilities [16].

\subsection{Modeling for Individual Trees}

One of the foresters had a little forest where he measured each tree, and we adapted the model to the scale of a tree, in order to determine the optimal intensity of clearing.

\section{Conclusion}

The main interest of this modelling operation was to associate the foresters to build the model, since its beginning. This was possible only because the model is understandable by non mathematicians in its principle and in its development.

\section{References}

[1] Forman R. T. T \& Godron M, 1986, Landscape Ecology, Wiley, $620 \mathrm{p}$.

[2] Godron M., 2012, Écologie et évolution du monde vivant, L'Harmattan, Paris, 3 vol.

[3] Godron M. 1961 Rapport sur la conversion des taillis sous futaie en futaie par bouquets, Centre d'études techniques forestières du Berry, $23 \mathrm{p}$.

[4] Godron M., 1966, Bases préliminaires pour établir un plan simple de gestion, Annales du comité central agricole de la Sologne, 3: 101-112.

[5] Godron M. 1972, Échantillonnage linéaire et cartographie, Investigacion Pesquera, 36 (1).

[6] Godron M. \& J. Poissonet, 1973, Phyto-écologie et aménagement cynégétique. Cas d'une région française: la Sologne, CNRS-C.E.P.E Louis Emberger, document 73, 18 p.

[7] Godron M. \&, Li Xiu-Zhen, 2001, Some questions about landscape modelling, Journ. of Environmental Sci., 13, 4: 459-465. 
[8] Dejous, J-F. (2019), Suivis annuels d'occupation des sols et ressources forestières Forêt-entreprise, 247: 25-30.

[9] Desprez-Loustau M.-L., Robin C., Reynaud G. 2007. Simulating the effects of a climate change scenario on geographical range and activity of forest pathogenic fungi. Can. J. Plant Pathol. 249: 246-253.

[10] Dufour-Kowalski S., Courbaud B., Dreyfus P., Meredieu, C., Coligny F. de. 2012, Capsis; an open software framework and community for forest growth modelling. Annals of Forest Science. 69: 221-233.

[11] Godron M. \& H. Joly, 2008, Dictionnaire du paysage Ed. CILF, 11 rue de Navarin 75009, $278 \mathrm{p}$
[12] Bergès L., Dupouey J.-L. 2017, Ecologie historique et ancienneté de l'état boisé. Rev. For. Fr. 4: 297-318.

[13] Godron M (2018) Three Direct Measures of Diversity for Forests. Curr Trends Forest Res: CTFR-116. DOI: 10.29011/ 2638-0013. 100016.

[14] Didolot F. 2019. Le climat une préoccupation commune pour des propriétaires et des entreprises. Forêt-entreprise. 245: 16-23.

[15] Naudts K et al. 2016 Europes forest management did not mitigate climate warming. Science 351: 597-600.

[16] Godron M. (prep.) Exact probabilistic methods for landscape ecology. 